\title{
TINGKAT STRESS MAHASISWA DENGAN TUGAS YANG DIBERIKAN PADA MASA PANDEMI COVID-19
}

\author{
Oleh: \\ ${ }^{1)}$ Ahmad Fauzi \\ Program Studi Psikologi, Fakultas Kedokteran, Universitas Lambung Mangkurat, Jl. A. Yani Km \\ 36 Banjarbaru Kalimantan Selatan, 70714, Indonesia \\ ${ }^{1)}$ Email: 2010914210007@mhs.ulm.ac.id \\ ${ }^{1)}$ Nomor Telepon: 0895704107128
}

\begin{abstract}
The covid-19 pandemic that occurred is certainly very influential in human life on earth from all aspects, everyone and all circles feel the impact. From the obstacles generated by this pandemic, even though it is difficult, do not become an excuse for being unproductive in terms of writing. But on the other hand, of course, the students also felt the impact of the pandemic this time, and what felt the most for the students was the number of assignments they were given. Of the many assignments given during online lectures, it creates a burden on the mind which has an impact on student academic stress. The hypothesis of this research is related to the psychological state of students, namely the relationship between the assignments given from online learning with the level of student academic stress. The research object this time was myself as a student with the research method used, namely literature review. The result of this research is the initial hypothesis that the relationship between the assignments given from online learning and the student's academic stress level is acceptable.
\end{abstract}

Key word: covid-19, online, writting, pandemic, stress

\begin{abstract}
ABSTRAK
Pandemi covid-19 yang terjadi tentunya sangat berpengaruh dalam kehidupan manusia di bumi dari segala aspek, semua orang dan semua kalangan merasakan dampaknya. Dari adanya hambatan yang dihasilkan oleh pandemi ini, walaupun susah jangan sampai menjadi alasan untuk tidak produktif dalam hal menulis. Tetapi disisi lain tentunya para mahasiswa juga merasakan dampak dari pandemi kali ini, dan yang paling terasa untuk para mahasiswa ialah banyaknya tugas yang diberikan. Dari banyaknya tugas yang diberikan dikala perkuliahan daring ini membuat beban pikiran yang berdampak pada stress akademik mahasiswa. Hipotesis penelitian kali ini berkaitan dengan keadaan psikologis mahasiswa yaitu keterkaitan antara tugas yang diberikan dari belajar daring dengan tingkat stress akademik mahasiswa. Objek penelitian kali ini adalah saya sendiri sebagai seorang mahasiswa dengan metode penelitian yang digunakan yaitu kajian literatur. Hasil dari penelitian ini ialah hipotesis awal yaitu keterkaitan antara tugas yang diberikan dari belajar daring dengan tingkat stress akademik mahasiswa bisa diterima.
\end{abstract}

Kata kunci: covid-19, daring, menulis, pandemi, stress 


\section{PENDAHULUAN}

Sedikit bercerita mengenai kebisaan saya dalam menulis, saya merasa bahwa diri saya tidak terlalu pandai menuliskan segala sesuatu ke dalam sebuah buku ataupun dalam bentuk file word. Tapi sebagai mana yang dikatakan Prof. Ersis Warmansyah Abbas. Dalam bukunya, Abbas (2016) mengatakan bahwa menulis tidak cukup berteori saja sebab menulis itu melakukan. Artinya dengan melakukan berarti bukan hanya melatih melainkan juga membiasakan diri. Maka dari hal inilah saya mencoba untuk memulai menulis.

Memang terasa susah kiranya untuk mencoba sesuatu yang jarang dilakukan, tetapi dengan berani mencoba untuk memulai maka tidak ada salahnya. Sebab dengan berani mencoba untuk, itu merupakan suatu proses untuk mencapai suatu kebiasaan yang nantinya juga akan berdampak positif jika itu memang merupakan hal yang positif. Tidak ada salahnya dalam mencoba untuk membiasakan menulis, kalimat itu merupakan kalimat yang mulai saya resapi dalam memulai untuk menulis. Menulis itu bersifat fleksibel, artinya penulis bisa melakukan dan mengerjakannya dimana saja dan kapan saja tanpa ada suruhan yang mewajibkan penulis ketika ingin menulis harus di tempat dan waktu yang khusus. Hal ini sesuai dengan yang dikatakan oleh Prof. Ersis Warmansyah Abbas dan Neka Erlyani S.Psi, M.Psi, Psikolog. Menulis kapan saja, dimana saja, dan ketika sedang melakukan apa saja (Abbas \& Erlyani, 2020).

Menurut Abbas (2020) setiap orang harus mampu memanage waktu, tenaga, kemampuan, dan sebagainya sehingga tidak dijadikan alasan untuk tidak taat aturan. Artinya, walaupun menulis tidak diberikan syarat khusus mengenai tempat dan waktu seorang penulis harus mampu mengatur waktunya agar tidak ada alasan untuk menulis. Orang yang gagal adalah orang selalu mencari alasan untuk tidak melakukan sesuatu ketika ada kesempatan untuk dirinya mendapat sesuatu yang baru untuk terus berkembang.

Menurut Abbas \& Erlyani (2020) Menulis meraup informasi melalui pancaindra atau mengaktifkan otak dengan berpikir, merelasikan pengetahuan di otak, sesungguhnya bukan saja menumpuk pengetahuan di otak, tetapi sekaligus membangun mindset. Saya mencoba memulai menuliskan sesuatu dengan apa yang saya lihat atau amati seperti melihat kejadiannya secara langsung ataupun tidak langsung, tidak langsung maksudnya saya melihat melalui media informasi lain. Baik dari televisi, koran, buku, ataupun media sosial. Dan apa yang saya dengar dari orang lain. Informasi apa saja yang diterima melalui pancaindera bisa dituliskan menjadi sebuah tulisan.

Abbas \& Erlyani (2020) menyebutkan menulis memperbaiki diri yang karena itu menjadi mengasyikkan apabila menulis menjadi beban, ingat beban itu di pikiran karena itu mulai bangun kebiasaan menulis agar pikiran tenang perasaan nyaman bak falling in love. Dalam hal ini, saya yang belum terbiasa untuk menulis sesuatu mencoba untuk membiasakan menulis sesuatu agar menjadi sebuah kebiasan dengan tujuan ketika disuruh untuk menulis maka itu bukan lagi menjadi beban, tapi malah saya menjadi senang dan santai menjalaninya.

Kejutan datang di akhir tahun 2019. Ya, covid-19 datang secara mengejutkan yang membuat keresahan bagi masyarakat 
dunia. Tak terkecuali di Indonesia. Ditahun 2020 perkembangan kasus covid-19 di Indonesia dan dunia terus berkembang yang membuat kondisi ini menjadi pandemi, rasa takut pastinya muncul dalam benak setiap orang akan tertular virus ini. Tapi tidak dapat dibohongi juga banyak orang yang tidak percaya akan virus ini. Pandemi ini berimpact pada kebutuhan pangan masyarakat, membuat masyarakat mengalami panic buying. Menurut Shadiqi et.al (2020) Panic Buying adalah keadaan dimana konsumen membeli barang dalam jumlah banyak bukan bertujuan untuk mencari selisih harga yang akan timbul antara masa sekarang dan masa yang akan datang, tetapi bertujuan untuk menghindari kekurangan pasokan yang mungkin akan terjadi di masa depan.

Sedikit mengerucut dari pembahasan mengenai covid-19 yang sifatnya umum ke hal yang lebih kecil yaitu kehidupan perkuliahan, tentunya perkuliahan juga mendapat dampak dari pandemi ini. Proses belajar mengajar berubah dari tatap muka menjadi daring saja. Memang benar dari pembelajaran daring yang mana memerlukan akses internet dahulu, dan dengan internet segala sesuatu menjadi lebih mudah. Hal ini sesuai dengan apa yang diungkapkan oleh Lu'lu'ul Fuadiah, dkk. Menurut Fuadiah et.al (2016) Internet memberikan kemudahan untuk mencari sumber informasi yang cepat sesuai dengan kebutuhan. Oleh karenanya umum digunakan oleh masyarakat, tak terkecuali kalangan mahasiswa. Tetapi kembali lagi, tentunya banyak hal yang perlu diadaptasi dari kebiasaan baru ini. Hipotesis penelitian ini adalah keterkaitan tugas yang diberikan dari belajar daring dengan tingkat stress mahasiswa.

\section{METODE PENELITIAN}

Objek penelitian pada penelitian kali ini adalah saya sendiri sebagai seorang mahasiswa, jadi saya melakukan penelitian dengan cara menganalisis hal apa saja yang saya rasakan selama masa pandemi seperti ini, terlebih pada aspek psikologis saat pandemi ini seperti saat perkuliahan dengan perlu banyaknya adaptasi terhadap hal-hal yang baru. Mengingat masa SMA dengan masa perkuliahan sangat terasa berbeda, saya sendiri merasakannya.

Terbiasa bersantai dimasa SMA ditambah lamanya waktu liburan akibat pandemi membuat saya menjadi sedikit terkejut dengan pola kehidupan yang ada di sini, di kampus Psikologi Fakultas Kedokteran Universitas Lambung Mangkurat. Banyaknya tugas online yang terus-menerus diberikan tentunya juga mempengaruhi keadaan psikologis saya, ditambah dengan pembelajaran via daring yang menurut sedikit susah untuk dipahami.

Tugas-tugas tadi, dengan kesibukankesibukan dari kegiatan yang ada di Fakultas Kedokteran Universitas Lambung Mangkurat ditambah dengan kebiasaan menunda-nunda. Membuat beberapa tugas menjadi menumpuk yang membuat ujung-ujungnya kesulitan dalam mengerjakan. Hal ini sesuai dengan apa yang dikatakan oleh Manna Amini, dkk. Menurut Amini et.al (2019) menyebutkan mahasiswa seringkali baru belajar jika mendapati pelajaran yang menarik dan jika sedang tidak ada hal penting yang harus dilakukan. Banyak pula mahasiswa yang menganut sistem musiman dalam belajar, menunda mengerjakan tugas karena belum sampai batas waktu yang ditentukan untuk mengumpulkan sampai akhirnya batas waktu tersebut tiba di ambang pintu. Perlu waktu 
bagi saya untuk menyesuaikan diri terhadap kehidupan baru ini serta saya harus bisa memanajemen waktu dengan baik untuk menghadapi tugas-tugas dan kegiatan baru yang akan datang nantinya.

Metode penelitian yang digunakan pada penelitian kali ini adalah dengan menggunakan kajian literatur dengan mengambil atau mengutip dari artikel, jurnal, ataupun buku yang dibuat atau dihasilkan oleh Prof. Ersis Warmansyah Abbas serta beberapa dari dosen Program Studi Psikologi Fakultas Kedokteran Universitas Lambung Mangkurat.

\section{HASIL DAN PEMBAHASAN}

2020 diawali dengan hal yang tidak dan kurang mengenakkan. Semua mulai berubah ditahun ini karena suatu pandemi yang jelas sangat menghambat kehidupan baik dari segi sosial bermasyarakat, ekonomi, ataupun hal lainnya yang jelas juga terdampak. Pandemi ini ialah pandemi covid19, dampak dari pandemi ini dirasakan oleh semua orang, semua kalangan tak terkecuali saya sendiri. Dampak yang saya rasakan ialah menjadi susahnya interaksi yang bisa dilakukan secara langsung, bahkan untuk bersekolah pun pada dasarnya kami diliburkan. Susah kiranya untuk melakukan interaksi dalam sesuatu yang terbatas lewat media sosial saja, tidak bisa bertemu langsung dalam suatu kelas. Rasa ingin bertemu dengan teman-teman tentunya sangat terasa dalam diri ini, tetapi kembali lagi bahwa mengingat kasus pertambahan pasien covid-19 terus bertambah membuat saya harus menahan rasa rindu ini. Saya yakin bahwa pandemi ini segera berakhir, namun ternyata pada kenyataannya pandemi ini terus berlanjut berbulan-bulan.
Tak terasa ternyata kami sudah sampai tahap dimana kami akan berpisah dan tidak lagi berada di ruang kelas yang sama, belajar bersama-sama. Ya, karena kami akan segera lulus. Waktu berjalan dengan cepat tanpa dirasa dan disadari kata pisah sudah tiba didepan mata, tidak banyak momen yang bisa kami abadikan karena semua berada dirumah masing-masing. Rasa senang setelah dinyatakan lulus, dan rasa sedih karena tak terasa sudah berpisah dengan mereka semua, serta rasa rindu yang sudah ada sejak pandemi ini mulai masuk ke Indonesia tergabung dan bercampur aduk tetapi karena pandemi ini yang seakan memaksa kita harus tetap di rumah dan tetap menjaga protokol yang sudah ditetapkan mau tidak mau kita harus menjalankan dan menaatinya.

Tiba dimana waktu saya untuk memilih bagaimana masa depan saya nantinya. Aku mencoba mengikuti Tes SBMPTN agar saya bisa berkuliah. Setelah mengikuti tes di Universitas Lambung Mangkurat dengan mengikuti protokol yang yang ada, menunggu hasil pengumuman diwaktu yang lumayan lama dengan penuh sabar. Tibalah waktu pengumuman hasil Tes SBMPTN-nya, saya segera mencoba mengakses website pengumumannya dan syukur alhamdulillah dari hasil pengumuman nama saya tercantum dan dinyatakan lulus di Program Studi Psikologi Fakultas Kedokteran Universitas Lambung Mangkurat.

Memasuki masa perkuliahan, banyak hal yang sangat berbeda dari masa SMA seperti pembagian jadwal mata kuliah, banyaknya tugas, dan etika yang lebih diutamakan di Program Studi ini. Terlebih ditambah dengan perkuliahan yang dilaksanakan secara daring membuat semua hal menjadi sedikit terkendala baik dari 
device yang memadai ataupun jaringan yang terkadang lelet, serta paket data yang sering habis karena pemakaian untuk media belajar daring yang bisa dibilang boros dalam hal penggunaan paket data. Hal ini tentu saja membuat perekonomian menjadi terpengaruh, dalam seminggu saya pasti membeli paket data yang harganya jika dikira-kira tentunya akan memberatkan untuk perekonomian. Disamping itu banyaknya tugas yang diberikan juga membuat pikiran menjadi terbebani, saya sadar bahwasanya jika menyinggung mengenai tugas pastinya tugas akan selalu banyak. Tetapi saya juga harus beradaptasi dengan keadaan, datang sebagai mahasiswa baru yang belum tau dan belum paham apa-apa soal perkuliahan banyak sekali dikejutkan dengan hal-hal yang sangat kontras dengan kehidupan masa SMA.

Saya yakin kuliah luring atau tatap muka saja sudah pasti memerlukan waktu adaptasi yang memakan banyak waktu untuk seorang mahasiswa baru. Apalagi untuk perkuliahan dengan proses belajar mengajar daring yang merupakan hal baru dilakukan di Indonesia. Banyak kebingungan atau cultural shock dan cultural lag yang dirasakan baik oleh mahasiswa ataupun tenaga pendidik seperti dosen.

Dengan banyaknya tugas-tugas yang diberikan tadi, saya sendiri merasakan ada tekanan yang lebih tentang ini. Ada rasa khawatir dan rasa takut yang muncul yang membuat diri saya mulai merasakan sedikit stress. Rasa khawatir dan rasa takut yang saya alami ialah lebih mengarah kepada mendapat nilai IPK yang rendah. Putri et.al (2020) mengatakan IPK merupakan hal yang sangat penting bagi kehidupan akademik mahasiswa karena nilai IPK berpengaruh pada masa studi, beasiswa, bahkan lamaran pekerjaan di masa mendatang.
Putri et.al (2020) menyebutkan IPK rendah dapat menjadi sumber stress bagi mahasiswa, sebab IPK rendah akan berdampak pada lamanya masa kuliah, tidak memungkinkan untuk menerima beasiswa, bahkan untuk melamar pekerjaan di masa mendatang. Sesuai dengan apa yang sudah dipaparkan sebelumnya, rasa takut saya akan rendahnya nilai IPK diperoleh menjadi hal yang membuat saya merasa sedikit stress dan terlalu memikirkan hal yang sebenarnya tidak perlu dipikirkan. Pratiwi et.al (2016) menyebutkan stress merupakan suatu bentuk tanggapan seseorang, baik secara fisik maupun mental terhadap suatu perubahan di lingkungan yang dirasakan mengganggu dan mengakibatkan dirinya terancam.

Menurut Pratiwi et.al (2016) Stress yang dialami individu sebenarnya berada dibawah kontrol orang itu sendiri karena masalahnya ada pada individu yang mempersepsikannya. Menyadari bahwa stress yang saya alami merupakan bentuk dari pemikiran saya sendiri yang terlalu berpikiran jauh kearah yang kurang tepat, maka dari itu saya mencoba untuk memperbaiki pola pikir saya yang sedikit tidak sesuai. Berani untuk mencoba hal baru, berani mencoba sesuatu yang belum pernah dirasakan sebelumnya. Mencoba untuk tidak terfokus tentang hasil akhir terlebih dahulu yaitu IPK, tetapi mulai untuk berfokus pada sesuatu yang menunjang pada hasil akhir itu sendiri yaitu belajar, mengerjakan dan mengumpulkan tugas tepat waktu, serta berorganisasi untuk menambah relasi.

Saya mencoba untuk mengikuti organisasi dengan tujuan untuk meningkatkan kemampuan berorganisasi lebih jauh. Serasi dengan apa yang dikatakan Muhammad Lutfi Ekayuda, dkk. Menurut Ekayuda et.al (2018) dengan mengikuti 
organisasi, mahasiswa dapat membangun relasi yang semakin luas dengan orang lain dan mendapatkan ilmu yang bermanfaat, yang belum tentu didapatkan saat perkuliahan di dalam kelas. Atas dasar ini juga yang memotivasi saya agar mendapat relasi yang lebih luas serta mencari pengalaman baru yang sebelumnya belum pernah saya rasakan.

Kebutuhan remaja terhadap teman sebaya yang semakin meningkat, membuat kuatnya pengaruh kelompok sebaya terhadap remaja (Mayara et.al, 2017). Dalam hal ini saya mencoba untuk mencari teman yang sejalan dengan saya karena mengingat dari pertemanan itu jelas sangat mempengaruhi keadaan seseorang. Saya sedikit selektif untuk memilih teman agar tidak terjerumus kejalan yang salah, bukan bermaksud untuk terlalu memilih-milih teman sebab saya juga yakin teman-teman baik di Program Studi Psikologi ataupun di organisasi yang saya ikuti merupakan orang yang baik. Tetapi disini saya perlu teman yang bisa saling support satu sama lain yang menjadi support system dalam kehidupan saya.

Perlahan permasalahan yang saya alami sedikit demi sedikit seiring berjalannya waktu mulai bisa saya atasi, saya mulai berdaptasi dengan pola kehidupan baru saat pandemi ditambah pola kehidupan baru di perkuliahan. Saya mulai memahami bahwa hidup tidak bisa terus-terusan bersantai, saya dituntut untuk terbiasa dengan keadaan yang memang pada dasarnya berat dilewati tetapi bukan berarti tidak bisa dilewati.

Dugaan awal bahwa stress yang dialami akibat dari banyaknya tugas yang nantinya berkaitan dengan IPK bisa diterima. Sebab rasa khawatir yang berlebih menjadikan stress muncul.

\section{KESIMPULAN}

Mulailah kebiasaan menulis, walaupun awalnya merasakan kesulitan dalam menulis karena awalnya tidak terbiasa dengan hal semacam ini. Tetapi jika terus dijalani maka tanpa disadari akan mulai terbiasa. Menulis tidak menuntut dengan syarat yang khusus seperti kapan kita harus mengerjakannya dan dimana kita mengerjakannya. Kita bisa menulis dimana saja dan kapan saja, tetapi perlu diingat bahwa seorang penulis harus mampu memanajemen waktunya. Dari manajemen waktu yang baik akan tercipta suatu karya tulisan yang juga baik tentunya.

Dari penelitian ini dapat diketahui bahwa kondisi disaat pandemi seperti ini merubah keadaan segala aspek kehidupan, tak terkecuali pendidikan. Salah satunya adalah perkuliahan, baik mahasiswa ataupun dosen pasti merasakan hal yang sangat berbeda yang belum pernah dirasakan dan dilakukan sebelumnya. Mahasiswa yang sering dihadapkan dengan tugas-tugas yang diberikan ketika pandemi ini, pastinya mengalami sedikit atau banyak guncangan psikologis. Terlebih terjadi pada mahasiswa baru yang belum terbiasa dan belum memahami bagaimana kehidupan kampus.

Stress yang dialami oleh mahasiswa ketika pandemi dengan tugas yang banyak benar terjadi. Hal ini terjadi karena rasa khawatir dan rasa takut yang berlebih tentang nilai IPK yang rendah diperoleh nantinya. Rasa khawatir dan rasa takut ini tentunya juga dipengaruhi oleh banyak dan padatnya jadwal yang terjadi, setiap minggu pasti ada kegiatan.

Rasa khawatir dan rasa takut ini pastinya dengan berjalannya waktu akan secara perlahan pasti akan menghilang. 
Sebab ketika sudah bisa beradaptasi dengan baik dengan pola kehidupan yang baru maka artinya sudah terbiasa dengan keadaan yang serba sibuk, baik sibuk karena tugas maupun sibuk karena ada kegiatan lain.

\section{DAFTAR PUSTAKA}

Abbas, E. W. (2016). Mengatasi Kesulitan Menulis.

Abbas, E. W., \& Erlyani, N. (2020). Menulis di Kala Badai Covid-19.

Amini, M., Mayangsari, M. D., \& Zwagery, R. V. (2020). Hubungan antara Kemandirian Belajar dengan Komitmen Tugas pada Mahasiswa Program Studi Psikologi. Jurnal Kognisia: Jurnal Mahasiswa Psikologi Online, 2(2), 149-152.

Anward, H. H., \& Erlyani, N. (2016). Peranan conscientiousness terhadap perilaku cyberloafing pada mahasiswa. Jurnal Ecopsy, 3(1).

Ekayuda, M. L., Mayangsari, M. D., \& Akbar, S. N. (2020). PERANAN CONSCIENTIOUSNESS TERHADAP KETANGGUHAN PENGURUS ORGANISASI MAHASISWA FAKULTAS KEDOKTERAN UNIVERSITAS LAMBUNG MANGKURAT. Kognisia prodi Psikologi FK ULM, 1(2), 149-157.

Mayara, B. H., Yuniarrahmah, E., \& Mayangsari, M. D. (2017). Hubungan Kepercayaan Diri dengan Konformitas Pada Remaja. Jurnal Ecopsy, 3(2).
Pratiwi, J. S., Anward, H. H., \& Febriana, S. K. T. (2016). Hubungan antara Persepsi terhadap Kebisingan dengan Stres Karyawan. Jurnal Ecopsy, 1(1).

Putri, C. P., Mayangsari, M. D., \& Rusli, R. (2020). PENGARUH STRES AKADEMIK TERHADAP ACADEMIC HELP SEEKING PADA MAHASISWA PSIKOLOGI UNLAM DENGAN INDEKS PRESTASI KUMULATIF RENDAH. Kognisia prodi Psikologi FK ULM, 1(2), 28-37.

Shadiqi, M. A., Hariati, R., Hasan, K. F. A., I'anah, N., \& Al Istiqomah, W. (2020). Panic buying pada pandemi COVID-19: Telaah literatur dari perspektif psikologi. Jurnal Psikologi Sosial.

WARMANSYAH ABBAS, E. R. S. I. S. (2020). Menulis di Era Covid-19: Memanage Trauma Psikologis Menghindari Psikosomatis. Menulis di Era Covid-19: Memanage Trauma Psikologis Menghindari Psikosomatis. 